Mahmoudi, Lubitow, and Christensen. "Reproducing spatial inequality? The sustainability fix and barriers to urban mobility in Portland, Oregon." Accepted for publication in Urban Geography. For up-to-date journal version with page numbers, please see: https://doi.org/10.1080/02723638.2019.1698865

\title{
Reproducing spatial inequality? The sustainability fix and barriers to urban mobility in Portland, Oregon
}

\author{
Dillon Mahmoudi ${ }^{1}$, Amy Lubitow ${ }^{2}$, and MacKenzie A. Christensen ${ }^{3}$
}

${ }^{1}$ Department of Geography and Environmental Systems, University of Maryland Baltimore County, dillonm@umbc.edu, corresponding author; '2Department of Sociology, Portland State University, alubitow@pdx.edu; ${ }^{3}$ Department of Sociology, University of California, Irvine, mackenac@uci.edu

\begin{abstract}
We explore how the language of "just sustainability" may become subsumed into a sustainability fix strategy, depoliticizing the utility of concepts such as justice and/or equity. Building from critical GIS insights, we combine digitized spatial data from participatory mapping exercises and community-organization-based focus groups in Portland, Oregon, regarding a proposed six-mile biking and walking path around downtown. We find that $80 \%$ of participants' typical travel destinations are outside of downtown Portland and that participants experience planning and sustainability in a highly localized manner, challenging the equity rationale of downtown investment. We argue the top-down planning model, which presumes the spatial diffusion of benefits is equitable, is inherently ahistorical and fails to benefit those in historically marginalized neighborhoods. Finally, we argue for the value of community-oriented research, which, in this case, inspired a coalition of community organizations to formally oppose a city-led project based on the inequitable distribution of infrastructure benefits.
\end{abstract}

Keywords: sustainability fix; mobility justice; spatial equity; bicycle planning

\section{Introduction}

The paper focuses on a six-mile oblong biking and walking path around the central business district of Portland, Oregon that was publicly unveiled in 2015 by the City of Portland's Bureau of Planning and Sustainability (BPS). The proposed top-down multimillion dollar "Green Loop" project appears aligned with broader planning goals related to climate change, equity and mobility outlined in the city's Climate Action Plan Progress Report (2017) and 2035 Comprehensive Plan (2016). Although funding for the final project remains unsecured and the specific design for the Green Loop is still under review, proposed design elements such as new open spaces, parks, as well as enhanced biking facilities are likely to require significant investments. BPS connects the Green Loop project to wider social and environmental goals such as health or equity. A brochure for the project shows a map of Portland, with the Green Loop at the center of the map and in the central business district, and residents from outer Portland neighborhoods connecting via streets to the central city. Text for the map states:

"The Green Loop will increase accessibility and activity for all Portlanders. While Portland is projected to grow substantially over the next few decades, it is safe to say that many of Portland's major public institutions, cultural attractions and regional destinations will remain in the Central City. The Green Loop will be free to use and will help Portlanders reduce transportation costs while helping to promote a healthy lifestyle" (City of Portland Bureau of Planning and Sustainability, 2017). 
Mahmoudi, Lubitow, and Christensen. "Reproducing spatial inequality? The sustainability fix and barriers to urban mobility in Portland, Oregon." Accepted for publication in Urban Geography. For up-to-date journal version with page numbers, please see: $\underline{\text { https://doi.org/10.1080/02723638.2019.1698865 }}$

In another presentation, feedback text, presumably from a resident, says:

"I want the Green Loop to provide access to disadvantaged communities and individuals. To bring families of color to the center of the city" (City of Portland Bureau of Planning and Sustainability, 2018, emphasis own).

These quotes are just a few of many, which highlight some of the equity, health, and spatial assumptions of the project. First, they assume that all city residents have the same capacities to access and benefit from the Green Loop, despite the project's downtown location and the reality of rapid population growth outside of the downtown area. Second, they acknowledge that the role of the central city project is to "bring" residents to the central city and that the benefit to outer Portland residents is through coming to the central city. Third, they acknowledge the reality that inner Portland is overwhelmingly white, in contrast to outer Portland. These quotes hint at the historical uneven and (under)development of the city (Goodling, Green, \& McClintock, 2015) that resulted in wide disparities in infrastructure such as the lack paved roads and sidewalks outside the central city amidst continued displacement of minorities and vulnerable populations from the central city (Gibson, 2007; Bates, 2013).

In this paper, we sought to understand how residents outside the central city might benefit or use the Green Loop project and what benefits if any they might derive from the Green Loop project. We sought to specifically talk to those whose voices may be marginalized or missed in traditional community outreach planning processes in response to the strong equity claims of the project. Building upon the literature on just sustainabilities, we show how access to a sustainability-themed amenity-presumed without adherence to the social and spatial structure of the city - is conflated as a solvent to longstanding issues of equity. Using focus groups and participatory mapping data from low-income residents and people of color who live outside of Portland's downtown core, we consider the extent to which increased accessibility to downtown investments is a sufficient metric for achieving equity through Portland planning processes.

Accessibility, in this case, is based on the city's notion that those outside the direct project area will benefit because residents can access the central city project via other connecting road and bike lanes. However, many of these connections are undeveloped or hypothetical. Therefore, we situate this paper within a broader nexus of scholarship in geography, equity, and political economy - specifically engaging the discourse on the post-political and the depoliticized framing of planning projects. In the city's public framing of the project, the benefits of the Green Loop will diffuse to vulnerable residents in neighborhoods that have been traditionally and historically marginalized in a process we call 'trickle-out.'

Scholarship on the "sustainability fix" document the ways in which development- and growth-oriented urban actors "fix" the stalling of capitalist investment in the built environment by integrating the language of sustainability (While, Jonas, \& Gibbs, 2004; 
Mahmoudi, Lubitow, and Christensen. "Reproducing spatial inequality? The sustainability fix and barriers to urban mobility in Portland, Oregon." Accepted for publication in Urban Geography. For up-to-date journal version with page numbers, please see: https://doi.org/10.1080/02723638.2019.1698865

Long, 2016) without adherence to sustainability goals (McCarthy \& Prudham, 2004; Prudham, 2009). We use sustainability fix - as a form of the spatial fix - to highlight the double-meaning of the word fix. On the one hand, the sustainability fix means the need for capital to diffuse across space and capture new natures. On the other hand, the sustainability fix means the concentration and agglomeration of capital specific places through "selective incorporation of environmental goals" in built-environment projects, allowing capital to enter back into circulation (While et al., 2004, 552). The renewed urgency around climate change creates the opportunity for large-scale sustainability fix projects and policies. This urgency may lead to the roll-out of depoliticized sustainable development policies which ignore social justice while accelerating gentrification and displacement (Lubitow \& Miller, 2013). Importantly, the depoliticized sustainability fix acts as a way for large-scale development projects to circumvent or subsume equity and sustainability-based barriers while garnering significant media praise for the participating municipalities, developers, and sustainability groups. Through an analysis of a proposed sustainable development project in Portland, Oregon - a "paradigmatic green city" (Goodling, 2019, 1) - this paper makes two contributions to the literature. First, the paper argues for a more nuanced spatial understanding of how sustainability fix development projects impact the spatial structure of cities. Evidence suggests that the language of "just sustainabilities" (Agyeman, Bullard, \& Evans, 2003) may become subsumed into a sustainability fix strategy, depoliticizing the utility of concepts such as justice and/or equity, further entrenching spatial patterns of unevenness. This process of depoliticization disconnects urban amenities from the social processes through residents enjoy benefits, and instead perceptions of benefit are problematically reduced to a proximity-based, trickle-out process of distribution. Second, the paper presents a novel "critical GIS" method which integrates community into the construction of spatial data, through bridging of qualitative and quantitative data, and research sharing (Schuurman, 2009; Thatcher et al., 2016).

In the next section of this paper we synthesize the literature on the depoliticization of planning processes, mobility justice, and sustainable urban development dynamics. We then include a detailed description of our research methods. A primary goal of this project was to oversample low-income residents and people of color in areas outside of the central city, and further away from the project location, that were at an increased risk of gentrification and still perceived to benefit from the project. We provide an in-depth understanding of the community engagement approach combining focus groups and GIS analysis to oversample vulnerable groups. In our findings sections, we combine the aggregate data from participatory mapping exercises and 8 large focus group conversations to illustrate that, for research participants, 80 percent of their typical travel destinations are outside of the central city and that primary challenges to daily mobility lie not in one's ability to travel downtown, but in moving in and around one's own neighborhood. We conclude this paper by challenging the equity rationale of central city investments that follow a top-down, hierarchical pattern of spatial diffusion and by 
Mahmoudi, Lubitow, and Christensen. "Reproducing spatial inequality? The sustainability fix and barriers to urban mobility in Portland, Oregon." Accepted for publication in Urban Geography. For up-to-date journal version with page numbers, please see: https://doi.org/10.1080/02723638.2019.1698865

articulating how a more decentralized understanding of mobility may better achieve equitable planning outcomes. We argue that the continued reliance on traditional methods of public engagement and an ongoing focus on downtown investments cannot hope to achieve equitable outcomes. We suggest that central city planning efforts, when presumed to have far reaching benefits for the entire urban area, fail to consider the myriad ways that social context and spatial inequalities relationally shape an individual's potential for mobility and accessibility.

\section{Frameworks of Mobility and Urban Development}

\section{Mobility and Development in Portland, Oregon}

The City of Portland's Bureau of Planning and Sustainability (BPS) is a city office tasked with a range of responsibilities related to land use, zoning, climate change, transportation, waste, and energy. As part of the city of Portland's 2035 Central City plan, BPS developed the idea of the Green Loop as a means of connecting the East and West sides of the Willamette River. The city has articulated the goals of the Green Loop project as linked to wider social and environmental goals such as improved health, increased equity, increased efficiency, and placemaking. The city problematically framed the goals as thought all city residents have the same capacities to access and benefit from the Green Loop, despite the central city project location and the growth throughout the city.

In contrast to the central city, the eastern and northern parts of the city lack the same pedestrian and bicycling infrastructure in the central and western parts of the city. Other mobility projects, like light rail, and green infrastructure, like bioswale retention curb cut-outs, have contributed to the displacement and exclusion of marginalized residents in gentrifying neighborhoods (Gibson, 2007; Goodling et al., 2015). Community groups, like OPAL Environmental Justice, have highlighted these contradictions directly to BPS in other community outreach and participation events since their founding in 2006.

A city-sponsored assessment of the potential economic impacts of Green Loop implementation found that property values would likely increase with new infrastructure. Properties closest to the Green Loop would experience the largest shift in values (Liu, 2016). In one model, an additional quarter-mile of bike facilities within a property's half-mile radius buffer zone was estimated to increase single-family home property values by approximately $\$ 3,155$. Being a quarter mile closer to the nearest bike facility increases these values by $\$ 607$ to $\$ 3,762$. Other economic impacts include a likely increase in short-term jobs and potentially beneficial outcomes due to increased foot traffic at local businesses (Liu, 2016). While modest financial benefits will emerge from the implementation of large-scale bike infrastructure, the benefits are most significant for more affluent homeowners in the central city. 
Mahmoudi, Lubitow, and Christensen. "Reproducing spatial inequality? The sustainability fix and barriers to urban mobility in Portland, Oregon." Accepted for publication in Urban Geography. For up-to-date journal version with page numbers, please see: https://doi.org/10.1080/02723638.2019.1698865

\section{Urban Transportation Development and Mobility Justice}

As an attempt "to [sustainably] enhance the economic value of urban space and attract mobile capital in the restless quest for wealth and accumulation" (While et al., 2004, 549), sustainability fix schemes have increasingly had to contend with new barriers. In some cases, sustainability fix urban planning projects appear to be apolitical, consensusbased, and sustainability-oriented, yet subordinate equity for capital accumulation (Checker, 2011). Equity has long been a barrier to capital accumulation schemes, sometimes dismissed outright as antithetical to the assumed or perceived social benefits of profit. In the United States, a resurgent coalition of advocates and activism have sought to make the pursuit of equity a primary objective for public projects (Krumholz $\&$ Forester, 2011). While distinct from sustainability fix strategies, scholars and activists have turned to just sustainabilities to address both long-term sustainability and environmental justice in public projects (Agyeman et al., 2003).

After the roll-out of redlining in the United States (Squires, Velez, \& Taeuber, 1991; Massey \& Denton, 1993; Aaronson, Hartley, \& Mazumder, 2017), the Interstate Highway era of the 1950s and 60s contributed to the ongoing reproduction of social inequality in urban America (Winner, 1989; Freilla, 2004). In cities like Chicago, Portland, New York, and Los Angeles, changes in the transportation infrastructure uprooted poor communities and communities of color and disrupted the social fabric of inner-city neighborhoods (Bullard \& Johnson, 1997; Bullard, Johnson, \& Torres, 2004; Gibson, 2007; Sanchez, 2008). Despite the emergence of national legislation designed to offset both the resulting spatial inequalities of major urban development projects (such as Title VI of the 1964 Civil Rights Act, 1994's Environmental Justice executive order \#12898), as well as local policies designed to attend to equity concerns, transportation amenities remain inequitably distributed (Beyazit, 2011; Bocarejo \& Oviedo, 2012; Karner \& Niemeier, 2013; McKenzie, 2013; Biggar \& Ardoin, 2017). Individuals who are low-income, non-white, and transit-dependent, despite being members of federally protected classes by the Federal Transportation Administration, have been found to experience diminished access, challenges in paying for transit, and longer travel times than more privileged riders (Fernando \& Porter, 2002; Sanchez, 2008; McKenzie, 2013).

The persistence of these inequities in many U.S. cities, despite the re-emergence of central city revitalization projects, has led to the development of interdisciplinary scholarship loosely framed as mobility justice. Scholars, taking a cue from grassroots transportation activism across the U.S., have developed an academic discourse to acknowledge how patterns of unequal distribution of power and resources in city planning exacerbate the historical legacies of racist and classist development projects. Mobility justice calls for a recognition of how historical injustices impact present inequalities; seeks to center community and activist voices in transportation planning efforts; and attempts to theorize the pathways by which urban planning becomes depoliticized. A particularly robust discourse on mobility justice concerning bicycling 
Mahmoudi, Lubitow, and Christensen. "Reproducing spatial inequality? The sustainability fix and barriers to urban mobility in Portland, Oregon." Accepted for publication in Urban Geography. For up-to-date journal version with page numbers, please see: https://doi.org/10.1080/02723638.2019.1698865

is illustrative of the trends within this literature and useful in providing the scaffolding for which to understand Portland's Green Loop (Rast, 2006; Martens, Golub, \& Robinson, 2012; Sheller, 2012; Lubitow \& Miller, 2013; Golub \& Martens, 2014; Hoffmann, 2016; Behrsin \& Benner, 2017).

Mobility justice is complementary to the planning practice and scholarship in spatial equity. Equity planning seeks to address these uneven and segregated geographies of mobility, with specific goals of increasing the options and opportunities in areas and to residents with the fewest options (Krumholz, 1982; Talen, 2011; Sheller, 2012; Martens, 2016). Outside of mobility scholarship, older studies establish how simple spatial inequities, from playground amenities (Talen \& Anselin, 1998) to environmental toxins (Bowen, Salling, Haynes, \& Cyran, 1995), have serious impacts on future accumulations of both amenities or hazards. More recently, scholars dismantled the problematic practice of reducing access to amenities or exposure to hazards to simple GIS analysis of spatial proximity or spatial distribution (Walker, 2009; Pellow, 2017). The uneven development of amenities and uneven distribution of hazards undergird the importance of existing scholarship on mobility justice and transportation development.

\section{Bicycling, Sustainability, and Equity}

As city planning agencies across the U.S. adapt and plan for the impacts of climate change, bicycle infrastructure investments have emerged as a popular and relatively inexpensive form of long-range transportation planning. In Portland, bicycling is often framed in transportation planning documents as a healthy and sustainable investment wherein the positive impacts of cycling (e.g., health outcomes or reduction of greenhouse gas emissions) are presumed to be equally as beneficial to all community members (Lubitow \& Miller, 2013; Hoffmann, 2016). ${ }^{1}$ Li and Joh problematize how the benefits of bicycle infrastructure are measured, arguing that the economic benefits, and their spatial distribution, are still poorly understood. They argue for an integration of bicycle plans and transit master plans; when bicycle planning is performed separately from broader transportation planning, the outcomes tend to reproduce existing modal inequalities (2017) without addressing equity in transportation planning decisions (Rast, 2006).

New cycling investments, when framed as equitable and broadly appealing public goods that require little public engagement in the planning process, are at risk of generating a set of development priorities that best serve affluent white cyclists living in expensive urban cores, while lower-income residents and cyclists of color are pushed further from housing and transit amenities (McKenzie 2013). Thus, large scale bike infrastructure projects represent a new iteration of "convention centers, sports stadia, Disney-worlds, harbour places, and spectacular shopping malls" (Harvey, 1989, 12) in a continued shift

\footnotetext{
${ }^{1}$ See for example, Portland's 2017 Climate Action Plan.
} 
Mahmoudi, Lubitow, and Christensen. "Reproducing spatial inequality? The sustainability fix and barriers to urban mobility in Portland, Oregon." Accepted for publication in Urban Geography. For up-to-date journal version with page numbers, please see: https://doi.org/10.1080/02723638.2019.1698865

toward a depoliticized entrepreneurial urbanism (Eisinger, 1988; Ward, 2003; Swyngedouw, 2014).

Further, when urban planners frame bicycle and pedestrian planning sustainable and/or equitable, the fast-tracking of infrastructure projects commonly curtails meaningful input from vulnerable community members (Cahen, 2016; Hoffmann, 2016). Specifically in Portland, these depoliticized (or post-political, see Rosol, 2014; Swyngedouw, 2014) sustainability and equity framed bicycle and pedestrian projects have a recent history of marginalizing those already on the outside of traditional planning processes (Lubitow \& Miller, 2013; Hoffmann, 2015). Transportation projects are a particularly sensitive topic in North Portland because of the history of transportation projects in the city. Targeted planning policies and auto-based infrastructure projects in Portland's post-war period systematically splintered North Portland's thriving AfricanAmerican communities (Gibson, 2007). Further adding to the tension, Portland's housing costs continue to be some of the fastest-growing in the U.S., and displacement through gentrification threatens vulnerable populations throughout the city (Bates, 2013). Within the context of these already fraught planning conditions, top-down sustainability- and equity-oriented plans and projects risk being new justifications to (re)produce uneven development within Portland (Goodling et al., 2015).

\section{Using GIS in Community-Engaged Research}

While geographers have traditionally used GIS as part of quantitative/spatial analytic methods, feminist scholars have increasingly called for the critical engagement of GIS as a method for examining the complex experiences of marginalized populations (Kwan, 2002; McLafferty \& Tempalski, 1995; S. Elwood \& Agnieszka Leszczynski, 2018). Thus a critical GIS is "concerned with socioeconomic, feminist, epistemological, ontological, and participatory elements of GIS" (Schuurman, 2009, 363). Through an integration of social, technical, and community aspects, a growing number of community organizations and geographers have begun integrating "critical GIS" within mixed methods research, as the development of digital technologies has expanded to include a much wider array of representational possibilities beyond numerical and quantitative techniques (Kwan, 2004; Thatcher et al., 2016). In particular, geographers have questioned the non-neutrality of geospatial technologies, asking who develops technologies, who uses those technologies, and for what purpose (Leszczynski, 2009; Leszczynski \& Elwood, 2015). These developments have allowed researchers to engage community members through public participation (PPGIS) and participatory mapping exercises aimed at capturing the spatial narratives of residents. In a case study conducted within two counties in Florida facing developmental pressure, Lowery and Morse (2013) integrated participatory mapping procedures within a focus group format to comprehensively understand the extent of individuals' spatial attachment. In a similar vein, Elwood's (2001)analysis of the use of GIS in community planning, found that GIS methods engage residents in reexamining the representations of their community 
Mahmoudi, Lubitow, and Christensen. "Reproducing spatial inequality? The sustainability fix and barriers to urban mobility in Portland, Oregon." Accepted for publication in Urban Geography. For up-to-date journal version with page numbers, please see: https://doi.org/10.1080/02723638.2019.1698865

produced by local governments. However, existing patterns of community participation may bias findings. By combining GIS with community-engaged research similar to what Biggar and Ardoin call "community listening sessions" (2017), we draw on the diversity of our sample to examine the complex narratives of populations unheard by central governing forces. We do so as part of a broader call to follow what Pereira et al. (2017) identify as a need to use novel methodologies which combine qualitative, participatory, and quantitative approaches to maintain the narratives of the participants as data. This research seeks to leverage GIS in research and as a participatory method to tell spatial narratives while simultaneously engaging residents to express their spatial representations of mobility. The resulting spatial data and community-based narratives provide a comprehensive understanding of Portland's spatial inequality.

\section{Participatory Mapping}

\section{Data Collection}

We present data below based upon eight focus groups totaling 86 participants conducted in Portland, Oregon, between October 2015 and March 2016. Each focus group included both group discussions and a participatory mapping exercise outlined in Table 1. Heeding the call from the literature (Sultana, Salon, \& Kuby, 2017), we sought to purposefully engage low-income residents and people of color in disadvantaged neighborhoods because standard channels of public engagement at the city planning level marginalize these voices.

Table 1. Methodological Approach

\begin{tabular}{clll}
\hline Method & Purpose & Data & Data Analysis \\
\hline $\begin{array}{r}\text { Group } \\
\text { Discussion }\end{array}$ & $\begin{array}{l}\text { Gather Community-Engaged data } \\
\text { about mobility patterns and } \\
\text { behaviors in neighborhoods } \\
\text { experiencing or at-risk of } \\
\text { gentrification in Portland. }\end{array}$ & $\begin{array}{l}\text { Qualitative group discussions } \\
\text { with 86 participants who were } \\
\text { primarily racial/ethnic } \\
\text { minorities and/or low income. }\end{array}$ & $\begin{array}{l}\text { Inductive coding for } \\
\text { thematic content }\end{array}$ \\
\hline Participatory & $\begin{array}{l}\text { Gather spatial data to help } \\
\text { Mapping }\end{array}$ & $\begin{array}{l}\text { Spatial data linked to } \\
\text { participant demographic } \\
\text { information. }\end{array}$ & $\begin{array}{l}\text { Digitizing spatial data, } \\
\text { hexagonal aggregation, } \\
\text { and spatial analysis. }\end{array}$ \\
& mobility patterns.
\end{tabular}

Also of importance to this project was a focus on neighborhoods either currently experiencing or at-risk of displacement and gentrification. Figure 1 shows the number of displacement risk factors by neighborhood as well as the locations focus groups. Table 2 shows aggregate census data on the neighborhoods we performed our focus groups in comparison to the city-wide census data as well as to the focus group participants. 
Mahmoudi, Lubitow, and Christensen. "Reproducing spatial inequality? The sustainability fix and barriers to urban mobility in Portland, Oregon." Accepted for publication in Urban Geography. For up-to-date journal version with page numbers, please see: https://doi.org/10.1080/02723638.2019.1698865

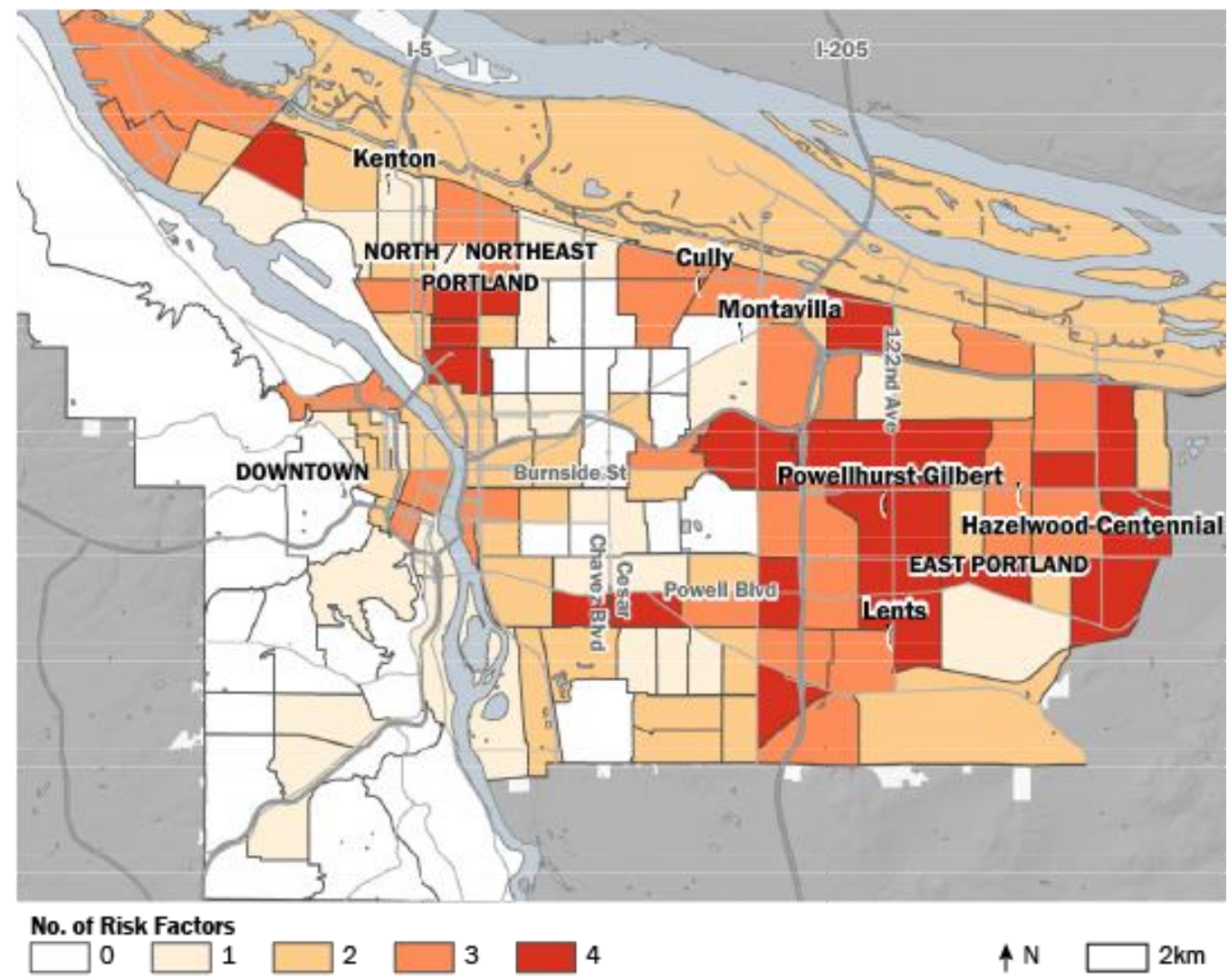

Figure 1. Reproduction of Bates' (2013) "Appendix A: Vulnerability Risk," with the current study's focus group neighborhood sites identified. Darker census tracts have a higher number of displacement risk factors. Author's conducted two focus groups in Cully and two in Hazelwood/Centennial.

\section{Participant Recruitment and Community Engagement}

Outreach to non-profit or social service organizations that serve immigrants, low-income individuals, people of color, and women resulted in three semi-formal partnerships (Rose Community Development Corporation, Rosewood Initiative, and Hacienda Community Development Corporation). In one neighborhood, at the request of our partner organization, the research team trained Spanish-speaking residents to co-facilitate two focus group discussions in Spanish. These collaborations generated valuable insights and culturally responsive research design. We recruited participants through the common channels of communication in each community organization, with additional support and management from the research team.

Table 2. Focus Group Neighborhood Census Demographics, as compared to Focus Group Participants in each Neighborhood. 
Mahmoudi, Lubitow, and Christensen. "Reproducing spatial inequality? The sustainability fix and barriers to urban mobility in Portland, Oregon." Accepted for publication in Urban Geography. For up-to-date journal version with page numbers, please see: https://doi.org/10.1080/02723638.2019.1698865

\begin{tabular}{|c|c|c|c|c|c|}
\hline $\begin{array}{ll}\text { Focus Group } \\
\text { Neighborhood }\end{array}$ & Census Tract & Non-White & 4YR Degrees & $\begin{array}{l}\text { Household } \\
\text { Income under } \\
20 \mathrm{k}\end{array}$ & $\begin{array}{l}\text { Median } \\
\text { Household } \\
\text { Income }\end{array}$ \\
\hline \multirow[t]{2}{*}{ Powellhurst-Gilbert } & CT 82.02 & $44 \%$ & $16 \%$ & $33 \%$ & $\$ 36,188$ \\
\hline & CT 92.01 & $28 \%$ & $11 \%$ & $30 \%$ & $\$ 21,906$ \\
\hline Kenton & CT 38.01 & $23 \%$ & $32 \%$ & $24 \%$ & $\$ 46,635$ \\
\hline \multirow[t]{3}{*}{ Cully } & CT 74 & $57 \%$ & $39 \%$ & $31 \%$ & $\$ 38,043$ \\
\hline & CT 75 & $48 \%$ & $25 \%$ & $20 \%$ & $\$ 50,437$ \\
\hline & CT 76 & $54 \%$ & $14 \%$ & $28 \%$ & $\$ 39,698$ \\
\hline \multirow[t]{4}{*}{ Montavilla } & CT 29.01 & $15 \%$ & $41 \%$ & $12 \%$ & $\$ 61,464$ \\
\hline & CT 29.02 & $22 \%$ & $32 \%$ & $9 \%$ & $\$ 50,042$ \\
\hline & CT 29.03 & $37 \%$ & $23 \%$ & $17 \%$ & $\$ 55,694$ \\
\hline & CT 77 & $34 \%$ & $19 \%$ & $18 \%$ & $\$ 42,689$ \\
\hline \multirow[t]{4}{*}{ Hazelwood-Centennial } & CT 93.01 & $46 \%$ & $23 \%$ & $30 \%$ & $\$ 43,250$ \\
\hline & СТ 96.06 & $59 \%$ & $7 \%$ & $32 \%$ & $\$ 31,688$ \\
\hline & СТ 97.01 & $36 \%$ & $10 \%$ & $25 \%$ & $\$ 16,900$ \\
\hline & CT 97.02 & $34 \%$ & $5 \%$ & $18 \%$ & $\$ 14,765$ \\
\hline \multirow[t]{3}{*}{ Lents } & CT 84 & $41 \%$ & $6 \%$ & $28 \%$ & $\$ 35,857$ \\
\hline & CT 85 & $32 \%$ & $8 \%$ & $17 \%$ & $\$ 43,489$ \\
\hline & СТ 90 & $35 \%$ & $9 \%$ & $27 \%$ & $\$ 38,521$ \\
\hline Portland City & & $28 \%$ & $32 \%$ & $19 \%$ & $\$ 53,230$ \\
\hline Study Sample & & $70 \%$ & $21 \%$ & $53 \%$ & NA \\
\hline
\end{tabular}

Note: Cully focus group in partnership with Hacienda Community Development Corporation, Hazelwood-Centennial focus group in partnership with Rosewood Initiative, Lents focus group in partnership with Rose Community Development.

We conducted three focus groups in the public meeting spaces at local library branches. Recruitment for these focus groups relied upon research team announcements at public meetings, fliers posted in the public library, in-person outreach at each library branch 12 weeks before the focus group, and through online platforms such as neighborhood association Facebook pages. We screened interested participants via a demographic questionnaire that asked basic questions about race, income, and neighborhood; prioritizing people of color or those individuals who reported an annual household income of less than $\$ 40,00$ for inclusion in the groups. At each focus group, we provided participants with food, childcare, a $\$ 25$ grocery store gift card, and translation services.

\section{Focus Groups and Participatory Mapping}

All participants were asked to complete a demographic questionnaire on the day of the focus group, though not all participants elected to complete every demographic question. As such, we report on the data we do have from our 86 participants. Most participants identified as black, Latino/a, or another non-white racial/ethnic group (59 of 86). More 
Mahmoudi, Lubitow, and Christensen. "Reproducing spatial inequality? The sustainability fix and barriers to urban mobility in Portland, Oregon." Accepted for publication in Urban Geography. For up-to-date journal version with page numbers, please see: https://doi.org/10.1080/02723638.2019.1698865

than $75 \%$ of participants reported an annual household income below $\$ 39,999$ (57 of 73 reporting), less than half of the median household income for the city. ${ }^{2}$ A majority of participants were women (73\%). There was an even spread of participants across age groups. This descriptive data of our participants, combined with Table 2, confirm that this research achieved its goal of including residents marginalized in traditional planning process. For this research we sought to explicitly talk to those whose feedback may have been overlooked or excluded by the City of Portland.

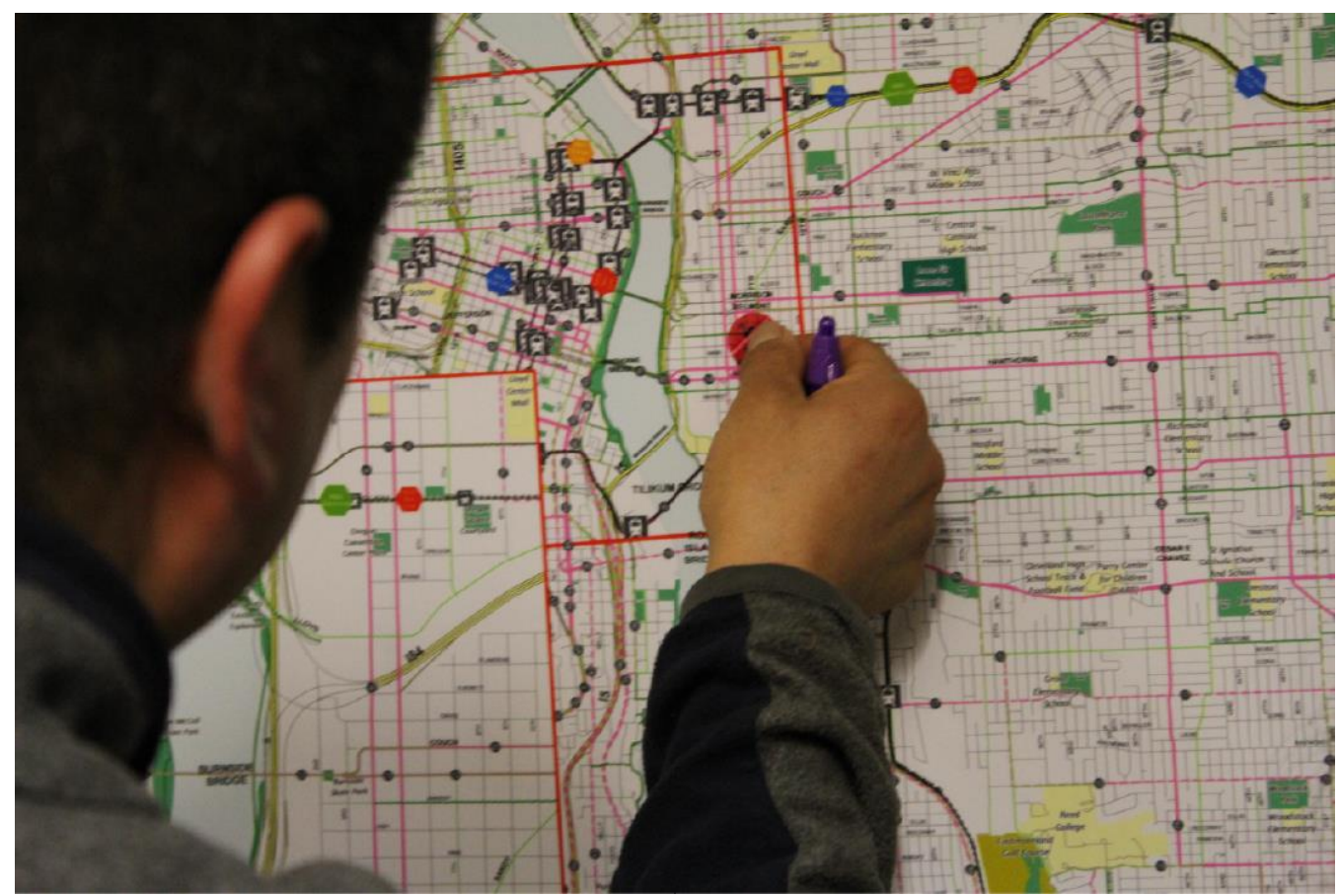

Figure 2. A participant places their coded sticky dot on the map to demarcate a barrier to their mobility.

Each focus group lasted approximately two-and-a-half hours. Focus group discussion and questions focused on barriers to mobility, neighborhood livability, movement to and from downtown, and perceptions of infrastructure changes in Portland. Discussions also solicited suggestions for enhancing movement and mobility within neighborhoods.

Following initial discussions of around 45 minutes, we provided participants with instructions about the mapping exercise. In every focus group, a new poster-sized map was generated for the neighborhood hosting the focus group. These maps included street

\footnotetext{
${ }^{2}$ For comparison, the 2012-2016 American Community Survey reports that households in City of Portland have a median income of $\$ 81,308$, households in the Portland-Vancouver-Hillsboro Metro Area have a median income of $\$ 83,175$, and households in the United States have a median income of $\$ 77,866$.
} 
Mahmoudi, Lubitow, and Christensen. "Reproducing spatial inequality? The sustainability fix and barriers to urban mobility in Portland, Oregon." Accepted for publication in Urban Geography. For up-to-date journal version with page numbers, please see: https://doi.org/10.1080/02723638.2019.1698865

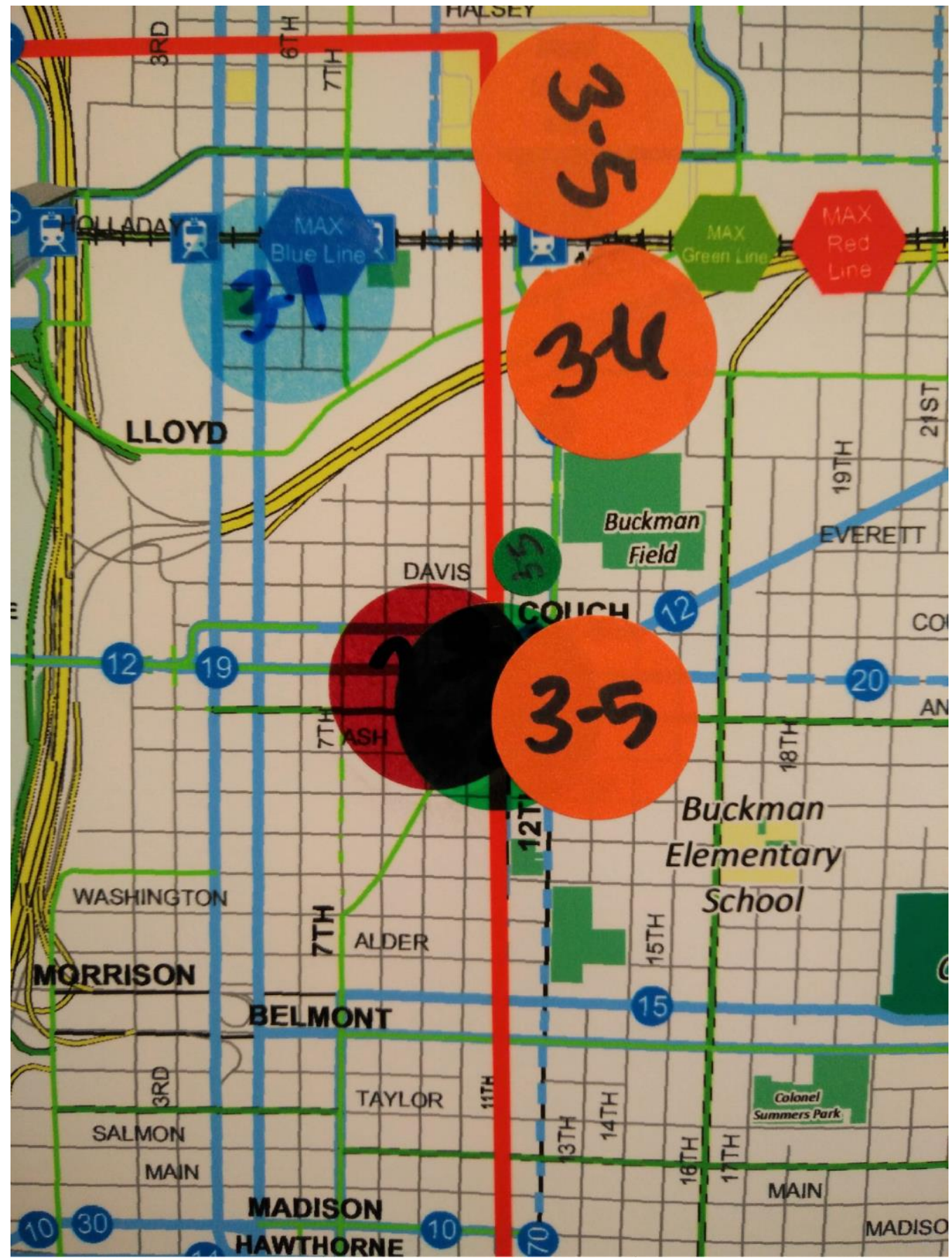

Figure 3. At the end of each mapping exercise, participants placed sticky dots on top of each relevant location. We digitized based on the center of the sticky dot. 
Mahmoudi, Lubitow, and Christensen. "Reproducing spatial inequality? The sustainability fix and barriers to urban mobility in Portland, Oregon." Accepted for publication in Urban Geography. For up-to-date journal version with page numbers, please see: https://doi.org/10.1080/02723638.2019.1698865

names, public transit routes, and green spaces. Each map also featured a section of the downtown area. Each participant had a series of sticky dots that were coded and linked to the demographic information they provided (though all information remained anonymous). Participants were asked to place four different types of sticky dots that corresponded to four different sets of places: a) places they go in an average week; b) places they don't go or avoid; c) areas that restrict mobility; d) barriers traveling to downtown from their neighborhood. After the mapping exercise, we asked to discuss their placement of dots. Figure 2 shows a participant placing a coded sticky dot. Figure 3 shows a cluster of coded sticky dots.

Focus groups were recorded, transcribed, and analyzed for thematic content. The research team inductively coded and analyzed transcripts for recurring concepts, using a multi-step process of constant comparison (Thomas, 2006; Bogdan \& Biklen, 2007; Corbin \& Strauss, 2014). The coding process entailed four steps in which the authors: (1) examined the transcript data for common concepts or themes; (2) sorted the data into the emergent thematic categories; (3) reread the transcripts and identified and compared our observations regarding patterns in the data to confirm or challenge emerging patterns; and (4) reviewed each transcript a final time to refine conceptual categories. This process resulted in a range of common themes or categories that inform the findings presented below.

\section{Spatial Analysis and Geocoding}

We entered each location and participant code of each sticky dot into a table for spatial analysis. Sticky dot locations were manually geocoded using the QGIS open source geographic information systems (GIS) software package. The table included the location, as a latitude and longitude, participant code, and type of sticky dot. Using the MMQGIS plugin for QGIS, we created a hexagonal grid which, according to the literature (for example Cortright, 2009), represented the average distance that a person was willing to walk in 20 minutes. We chose this distance and time to match BPS' previous analysis on "20-minute" neighborhoods (City of Portland Bureau of Planning and Sustainability, 2010). Each hexagon was approximately $1.66 \mathrm{~km}$ in area and $1.6 \mathrm{~km}$ along the diagonal. The count of each sticky dot type collected during the focus groups was computed for each hexagon, retaining the identifier for each participant.

\section{Results}

\section{Spatial (Im)mobility in Portland}

Although the participatory data collected in this study may be limited by an individual's recall and their relative confidence in locating a particular intersection or space on a map, the benefit of combining participatory data with focus group data is in helping to clarify how or why travel patterns look the way they do. Despite the fact that more technologically-oriented measurements might yield more precise data points, the utility 
Mahmoudi, Lubitow, and Christensen. "Reproducing spatial inequality? The sustainability fix and barriers to urban mobility in Portland, Oregon." Accepted for publication in Urban Geography. For up-to-date journal version with page numbers, please see: https://doi.org/10.1080/02723638.2019.1698865

of a mixed-methods approach is in helping to understand the nuances of mobility and the stories behind travel choices.

We tabulated 370 sticky dots within our area of study representing locations that residents typically travel in a week. Figure 4 shows that only 49 points (of 370), placed by 27 individuals, are located in the proposed Green Loop project loop area. That is, in a typical week, 87 percent of typical travel destinations fall outside of the Green Loop. Almost two-thirds of the study participants would not have direct access or the opportunity to utilize the Green Loop project.

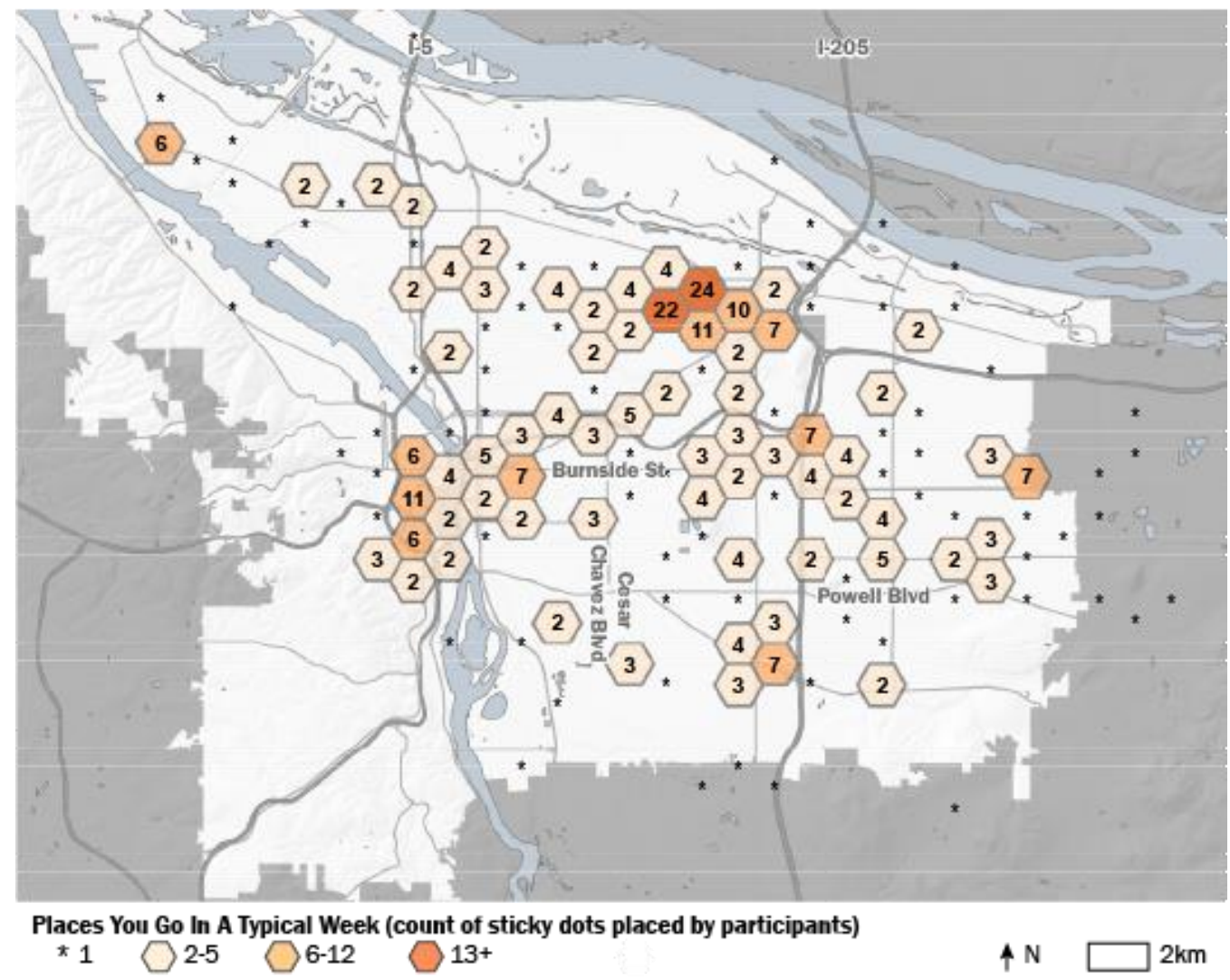

Figure 4. After digitizing participant sticky dots for "places you typically travel in a week" for all eight focus groups, points were aggregated using hexagonal bins.

When asked about their typical travel concerning the central city, participants either didn't want to travel downtown or found that there were barriers to doing so. Traveling to and from the central city was not of immediate interest for a clear majority of our participants, despite the Green Loop project's goals of creating infrastructure that would serve a large share of Portland residents. As one participant put it: 
Mahmoudi, Lubitow, and Christensen. "Reproducing spatial inequality? The sustainability fix and barriers to urban mobility in Portland, Oregon." Accepted for publication in Urban Geography. For up-to-date journal version with page numbers, please see: https://doi.org/10.1080/02723638.2019.1698865

"And the reality is that a lot of people who now live here don't or can't work downtown because toward downtown requires higher education. And it requires you being in very specific industries... a lot of folks are working in blue-collar industries...So a lot of our folks who live here, downtown isn't where people are going to work."

Analyzing the numbers for participants' reported barriers to mobility produced similarly stark results as those for traveling downtown. Figure 5 shows the results of the aggregated sticky-dots for all eight focus groups. Of the 224 sticky dots within our study area, representing barriers to daily or routine mobility, participants placed only 29 sticky dots near or in the Green Loop project area. Overwhelmingly, participants reported that what made it hardest for them to be mobile were neighborhood-level issues; not obstacles to downtown travel.

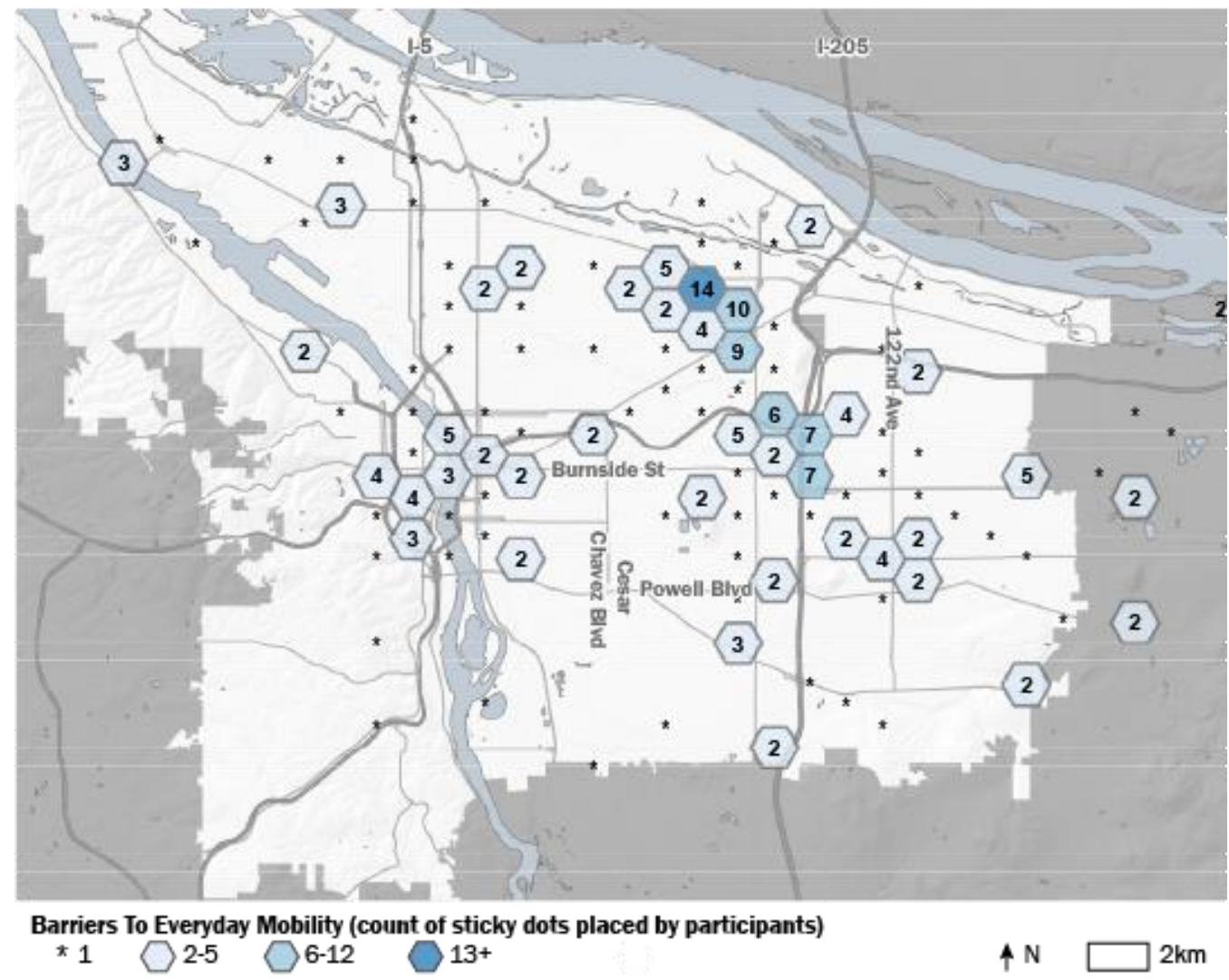

Figure 5. After digitizing participant sticky dots for "barriers to your everyday mobility" for all eight focus groups, points were aggregated using hexagonal bins.

Spatially-identified barriers to mobility emerged in focus group discussions as basic infrastructural problems such as a lack of sidewalks or well-lit and safe public transit 
Mahmoudi, Lubitow, and Christensen. "Reproducing spatial inequality? The sustainability fix and barriers to urban mobility in Portland, Oregon." Accepted for publication in Urban Geography. For up-to-date journal version with page numbers, please see: https://doi.org/10.1080/02723638.2019.1698865

stations. Several respondents commented on the lack of sidewalks in key places, such as near schools or bus stops. One participant expressed the stress of unimproved infrastructure:

"Nearby where I live, my daughter walks home from school... and there are no sidewalks for her to walk there. So it's really concerning for me. I have to come out and make sure she's not going to get hit by a car because they kind of go fast, even though there are [speed] bumps."

Another participant expressed their unease of the lack of sidewalks:

"Sidewalks aren't really an issue because there aren't any [laughing]... My wife is blind with a cane. And it's pretty hard to navigate around there when everything looks the same. So that's a big issue for her."

Publically visible and ongoing investment in downtown infrastructure appeared to many respondents to be at the expense of the outer neighborhoods of the city where our focus groups took place.

"[The city is not] consistent with the bike lanes. Downtown gets a lot of love for the bike lanes but hardly anywhere else..."

The disparity between bike infrastructure in the central city versus outer neighborhoods produced similar discussions. Participants noted that the central city had special bikeways and traffic calming, but the bike lanes in the outer neighborhoods were along main thoroughfares.

"I ride my bike quite a lot and have the same troubles as walkers. It's kind of frightening on the main streets. Like one right out here, coming up from that way, I don't know if there's a dedicated bike lane on 122nd. But even if there is, it's right next to somebody who's doing forty or forty-five [miles per hour], it's kind of nerve-wracking."

Participants perceived the proposed Green Loop as continued investment in the downtown core that came at the expense of other neighborhoods, where basic barriers to daily mobility presented challenges that took precedence over any needs related to traveling downtown.

\section{Planning and Development, as Usual?}

In every focus group, participants noted without prompt the uneven infrastructure investments between downtown Portland and the outer neighborhoods. When asked explicitly about their interest in additional biking and walking infrastructure investments downtown, participants were overwhelmingly opposed (though many did agree that having an attractive downtown was a positive notion). The question often brought up 
Mahmoudi, Lubitow, and Christensen. "Reproducing spatial inequality? The sustainability fix and barriers to urban mobility in Portland, Oregon." Accepted for publication in Urban Geography. For up-to-date journal version with page numbers, please see: https://doi.org/10.1080/02723638.2019.1698865

feelings of inequity experienced daily by participants, prompting them to openly interrogate the city of Portland's funding priorities.

After being given a primer on the proposed Green Loop, we asked participants how this additional infrastructure might impact their travel within the city. Participants directly contradicted the city's equity claims - that the Green Loop would enable and encourage participants to travel downtown in healthy ways - rather, participants felt that the project failed to address their frustration in existing infrastructure as it wouldn't increase the frequency of their downtown travel or address existing barriers to mobility. In the Kenton neighborhood's focus group, a respondent noted the "love" that the central city receives:

"I feel like downtown Portland gets a lot of love already. And I know that there are needs [in this neighborhood], particularly Greeley [Avenue]. And I know the City is aware of that. And why that's not prioritized is not clear to me." [Group agreement]

In the Gregory Heights focus group, a similar conversation emerged:

Respondent 9: "They kind of need to stop paying attention to [downtown]."

[Lots of agreement]

[Group laughing]

Research Facilitator: "So investing in the Central City is not necessarily going to encourage you to go down there more?"

Respondent 3: "No."

Respondent 5: "It's just going to piss us off."

Respondent 8: "It's just magnifying inequity in the city. The city is so inequitable. It really is."

Respondent 8 above went on to say,

"Any time we talk about like where we're putting money, it's always about the West Side. You know, everybody is getting displaced out this way [the East side]... And they're getting pushed to places that still don't have bus...You know, once that [new] infrastructure comes in, it seems like those are the people that are leaving, you know, they just continue to get pushed and pushed. Whereas, I think anytime we start talking about West Side stuff and putting more money in West Side it really, to me, magnifies what Portland does to people."

Some participants expressed a desire for increased bike safety downtown and, overall, half a dozen people did note that enhanced central city infrastructure might encourage 
Mahmoudi, Lubitow, and Christensen. "Reproducing spatial inequality? The sustainability fix and barriers to urban mobility in Portland, Oregon." Accepted for publication in Urban Geography. For up-to-date journal version with page numbers, please see: https://doi.org/10.1080/02723638.2019.1698865

them to ride their bikes downtown. However, there was broad agreement among participants across focus groups that they would rather see resources funneled into more sidewalks and bike lanes in outer neighborhoods where infrastructure lagged as compared to the central city.

Participants noted that improved bicycling infrastructure within outer neighborhoods would have a more significant impact on their daily lives and would increase livability within their local area. At the Rosewood Initiative focus group, for example, one participant pointed out the interconnected nature of safe streets, bike lanes, and neighborhood vitality:

"Maybe if that kind of stuff they're doing in the bike lanes [downtown], if it was out here, then I think the environment would change. Number one, I don't think there would be as much crime. I think people would be more aware and how... they can't just...come driving down here real fast anymore, you know what I'm saying? [This neighborhood] needs to change... in order for it to change, the city is going to have to do something about the bike lanes, on this street [162nd Avenue]."

Public framing of the Green Loop project continues to center on the economic, health, and equity benefits of additional downtown infrastructure. Despite the potential for the Green Loop to connect into existing bike routes that tie to neighborhoods outside of the central city, our data demonstrates that many of Portland's most vulnerable residents live and work too far from the Green Loop to experience direct benefits. For most, basic challenges to mobility deter even neighborhood-level walking and biking; accessing the Green Loop for recreational purposes would seem to be less important than infrastructure in their own neighborhoods. One participant in the Kenton focus group phrased it this way:
"So I think, especially like in this neighborhood, I'm wanting to see...Knowing the changing demographics of a lot of these neighborhoods in outer Portland, because we're always talking about downtown, which I've kind of noticed a lot of your focus is like, when you get downtown...Like, forget downtown. Like, let's look at outer Portland. How do we change this built environment that's a suburban car-oriented environment, when we have a lot of people who aren't car drivers, mostly because you can't afford it?"

Participants also expressed skepticism regarding the climate-related benefits of central city infrastructure projects. At the Kenton focus group, two participants suggested that the project's central city emphasis contradicted other aims of enhancing environmentally beneficial active transportation choices in all neighborhoods:

R2: I think it's time to get away from just funneling people from outside into the Center and back again, because I think that's sort of ... 
Mahmoudi, Lubitow, and Christensen. "Reproducing spatial inequality? The sustainability fix and barriers to urban mobility in Portland, Oregon." Accepted for publication in Urban Geography. For up-to-date journal version with page numbers, please see: https://doi.org/10.1080/02723638.2019.1698865

R8: (interrupting) ... well, and that also sort of goes against what my understanding of planning and sustainability promotes, which is living in the neighborhood...or living fully in the neighborhood that you call home.

The city's use of equity and sustainability to validate the Green Loop's goals and to gain public support depoliticizes the project's impacts. Our findings show that the Green Loop project reproduce spatial inequalities of the city and limit the potential for truly equitable outcomes. This last interaction in the Kenton focus group demonstrates what the mapping exercises documents: our participants experience planning and sustainability locally and in their neighborhoods. The Green Loop project planning assumes that the potential for access, regardless of actual use, will benefit all city residents ignorant of the existing urban spatial structure and existing systems of structural inequality. While the project may indeed directly benefit those who live within a one-mile radius, these benefits fall off further from the central city. In this way, the project represents top-down urban planning that attempts to equate equity with one's potential access to an amenity, even when that amenity in unlikely to be utilized by lowincome communities or communities of color.

\section{Conclusion}

Despite Portland's long history of public engagement in planning processes and its reputation as a city of planning "best practices" (Dill et al., 2004), Portland is not immune from planning processes which can exclude vulnerable populations from important infrastructure investment. Local organizations (such as OPAL Environmental Justice Oregon, Verde, Living Cully and APANO), are at the forefront of an on-going battle for just planning processes and equitable infrastructure planning. Our participants voiced similar concerns, showing how the development of transportation infrastructure is more than just bike lanes or sidewalks, but instead a process of city making and community building. The city's Green Loop depoliticization through sustainability and equity justification - as a sustainability-fix - rests on social, environmental, and economic benefits that are overwhelmingly likely to serve already-privileged populations in the central city. Ongoing interest in development and infrastructure upgrades in downtown Portland is at odds with the city's findings that households outside the central city, where our focus group participants lived, show a higher current and future growth rate than households in the central city (City of Portland Bureau of Planning and Sustainability, 2012).

Predicted growth patterns in Portland, therefore, require a spatial equity planning process that considers existing spatial inequalities in infrastructure and transportation choices, and seeks first and foremost, to ameliorate some of those disparities (Krumholz, 1982; Talen \& Anselin, 1998; Krumholz \& Forester, 2011). Continued reliance on traditional methods of public engagement and an ongoing focus on downtown investments cannot hope to achieve equitable outcomes in a city which is starkly spatially divided. Our data 
Mahmoudi, Lubitow, and Christensen. "Reproducing spatial inequality? The sustainability fix and barriers to urban mobility in Portland, Oregon." Accepted for publication in Urban Geography. For up-to-date journal version with page numbers, please see: https://doi.org/10.1080/02723638.2019.1698865

suggest that low-income individuals and people of color at the periphery of "Portland" face persistent and troubling barriers to daily mobility in their immediate environment.

In the city's public framing of the project, the social benefits of the Green Loop will diffuse to vulnerable residents by trickling-out of the central city in a non-social and purely spatial form of trickle-down economics. The Green Loop is continually depoliticized and justified by the claim that everyone in the city has universal access to, and thus benefits equally from, the project. We show how development based on a sustainability fix hinders an equity evaluation whose primary metric is access to central city amenities, where "access" is perceived to be a mechanism that serves traditionally marginalized populations. The uneven spatial structure of the city instead reveals that wealthier, white central city residents have much higher rates of access to the proposed project than those connected to the project later through bike and pathway development. The same affluent residents most likely to benefit from central city investments are also most likely to be included in public engagement processes. For residents outside the central city, involvement in the planning process is top-down: planners tell participants how the project will benefit them with little or no potential for providing meaningful feedback. Their already limited mobility may preclude them from participating in central city planning processes, which often occur downtown.

Green Loop proponents and urban planners design the project with spatially concentrated urban elites in mind and justify the project by problematically suggesting broad, equitable benefit through trickling out from the central business district. We showed how the access to depoliticized sustainability-themed Green Loop-presumed without adherence to the social and spatial structure of the city-is conflated as a solvent to longstanding issues of structural and spatial equity. Our findings suggest that the most vulnerable residents outside the central city often avoid traveling downtown and that the proposed project would not change their travel behavior. Contrary to the belief of city planners, focus group participants identified the need for basic infrastructure upgrades in their neighborhoods as having a greater impact on their mobility than the Green Loop. We, therefore, argue that when central city planning efforts are presumed to have farreaching benefits for the entire urban area, without thoughtful consideration of the ways that social context and spatial inequalities shape an individual's potential for mobility, such efforts risk contributing further to social and spatial inequalities.

In closing, we highlight a recent incident related to the Green Loop that is illustrative of the limitations of using an equity frame to justify a central city infrastructure project, when such claims presume spatial equality. In the fall of 2017, a group of community organizations - predominately serving communities of color-sent a letter to the mayor of Portland and the Portland City Council to voice opposition to the Green Loop based on ongoing inequity in public investments. The letter noted that: 
Mahmoudi, Lubitow, and Christensen. "Reproducing spatial inequality? The sustainability fix and barriers to urban mobility in Portland, Oregon." Accepted for publication in Urban Geography. For up-to-date journal version with page numbers, please see: https://doi.org/10.1080/02723638.2019.1698865

"The Green Loop fails to meet even the simplest understanding of equity... numerous areas outside of the City core lack even the most basic pedestrian and bike safety infrastructure... vision at the expense of critical and much-needed investments outside of the City core serve only the elite."

This articulation of unjust sustainability-themed city-making reflects ongoing challenges to (re)politicize the planning processes around the visioning, development, and implementation of urban spaces and suggests the ongoing need to integrate a spatiallyaware understanding of community interests and needs in public design processes. The threat of depoliticization entrenches the on-going, violent, and racialized city-making process that is often seen simply as what Ananya Roy calls dismissive "unintended consequences," justifying the failure of planning projects "to think about complex social systems through which plans must be implemented" $(2005,156)$.

In Portland, local community-based organizations have consistently utilized a social justice lens to influence seemingly mundane public policies at the city level. A coalition of justice-oriented organizations has claimed numerous transportation and infrastructure-related victories, including, but not limited to, the introduction lowincome fares, extended bus transfer time-limits, the creation of a youth pass for nonpublic school students, and the repeal of a statewide ban on Inclusionary Zoning. In the case of the Green Loop project, academic research provided data that community organizations leveraged in service of a broader critique of the city's notion of equity. Thus, we close by emphasizing the crucial nature of academic research that utilizes knowledge to amplify community voices in ways that politicize and reshape city-making processes.

Funding: This work was supported by the Institute for Sustainable Solutions at Portland State University, as part of the Portland Climate Action Collaborative.

Disclosure: No potential conflict of interest was reported by the authors.

\section{Acknowledgements}

The authors are grateful for the many students whose labor made this communityengaged research possible: Nathan Rochester, Emma Deppa, Raquel Nasser, and Kyla Tompkins. The research team would like to thank, Beth Gilden and Fletcher Beaudoin of ISS, The Rosewood Initiative, Community Cycling Center, Hacienda CDC, Rose CDC, The Bicycle Transportation Alliance, OPAL Environmental Justice Oregon and The Multnomah County Library (particularly the Kenton, Gregory Heights, and Midland Branches) and the audience at the Boston meeting of American Association of Geographers. Finally, we are grateful to members of the Human Geography Roundtable at UMBC, Ingrid Behrsin, Tara Goddard, Jamaal Green, and two anonymous reviewers for their insightful comments. All errors are our own. 
Mahmoudi, Lubitow, and Christensen. "Reproducing spatial inequality? The sustainability fix and barriers to urban mobility in Portland, Oregon." Accepted for publication in Urban Geography. For up-to-date journal version with page numbers, please see: https://doi.org/10.1080/02723638.2019.1698865

\section{References}

Aaronson, Daniel, Hartley, Daniel A., \& Mazumder, Bhashkar (2017). The Effects of the 1930s HOLC "Redlining" Maps. Chicago, Illinois: Federal Reserve Bank of Chicago.

Agyeman, Julian, Bullard, Robert D., \& Evans, Bob (Eds.) (2003). Just Sustainabilities: Development in an Unequal World (1 edition.). Cambridge, Mass: The MIT Press.

Bates, Lisa K. (2013). Gentrification and Displacement Study: implementing an equitable inclusive development strategy in the context of gentrification. Portland, Oregon: Bureau of Planning and Sustainability.

Behrsin, Ingrid, \& Benner, Chris (2017). Contested spaces and subjectivities of transit: Political ecology of a bus rapid transit development in Oakland, California. Journal of Transport Geography, 61, 95-103.

Beyazit, Eda (2011). Evaluating social justice in transport: lessons to be learned from the capability approach. Transport reviews, 31(1), 117-134.

Biggar, Matt, \& Ardoin, Nicole M. (2017). Community context, human needs, and transportation choices: A view across San Francisco Bay Area communities. Journal of Transport Geography, 60, 189-199.

Bocarejo, Juan Pablo, \& Oviedo, Daniel Ricardo (2012). Transport accessibility and social inequities: a tool for identification of mobility needs and evaluation of transport investments. Journal of Transport Geography, 24, 142-154.

Bogdan, Robert, \& Biklen, S. (2007). Qualitative research for education: An introduction to theory and practice. Boston: Allyn and Bacon.

Bowen, William M., Salling, Mark J., Haynes, Kingsley E., \& Cyran, Ellen J. (1995). Toward environmental justice: Spatial equity in Ohio and Cleveland. Annals of the Association of American Geographers, 85(4), 641-663.

Bullard, Robert, \& Johnson, Glenn (Eds.) (1997). Just Transportation: Dismantling Race and Class Barriers to Mobility (Presumed First Edition edition.). Gabriola Island, BC; Stony Creek, CT: New Society Publishers.

Bullard, Robert, Johnson, Glenn, \& Torres, Angel (Eds.) (2004). Highway Robbery: Transportation Racism and New Routes to Equity (1st edition.). Cambridge, Mass: South End Press.

Cahen, Claire (2016). "More Than Paint on Concrete": The Winding Path toward Bike Equity. Global Journal of Community Psychology Practice, 7(3), 2-9.

Checker, Melissa (2011). Wiped Out by the "Greenwave": Environmental Gentrification and the Paradoxical Politics of Urban Sustainability. City \& Society, 23(2), 210-229.

City of Portland Bureau of Planning and Sustainability (2010). 20-Minute Neighborhoods. Portland, Oregon: Bureau of Planning and Sustainability.

City of Portland Bureau of Planning and Sustainability (2012). Buildable Lands Inventory Summary of Future Development Capacity. Portland, Oregon: City of Portland Bureau of Planning and Sustainability.

City of Portland Bureau of Planning and Sustainability (2017). The Green Loop Brochure,. Retrieved from https://www.portlandoregon.gov/bps/article/478158.

City of Portland Bureau of Planning and Sustainability (2018). The Green Loop Presentation,. Retrieved from https://www.portlandoregon.gov/bps/article/542082.

Corbin, Juliet, \& Strauss, Anselm (2014). Basics of Qualitative Research. Thousand Oaks, California: Sage.

Cortright, Joe (2009). Walking the walk: How walkability raises home values in US cities. Cleveland, Ohio: CEOs for Cities.

Dill, Jennifer, Yeakley, Alan, Witt, Mattew, Johnson, Steven Reed, Sussman, Gerald, Estes, J. R., ... Mayer, Heike (2004). The Portland Edge: Challenges And Successes In Growing Communities. (Connie P. Ozawa, Ed.) (4th ed. edition.). Washington, DC: Island Press.

Eisinger, Peter K (1988). The Rise of the Entrepreneurial State: State and Local Economic Development Policy in the United States. Madison, Wis.: University of Wisconsin Press.

Elwood, Sarah A. (2001). GIS and Collaborative Urban Governance: Understanding Their Implications for Community Action and Power. Urban Geography, 22(8), 737-759. 
Mahmoudi, Lubitow, and Christensen. "Reproducing spatial inequality? The sustainability fix and barriers to urban mobility in Portland, Oregon." Accepted for publication in Urban Geography. For up-to-date journal version with page numbers, please see: https://doi.org/10.1080/02723638.2019.1698865

Elwood, Sarah, \& Agnieszka Leszczynski (2018). Feminist digital geographies. Gender, Place \& Culture, 25(5), 629-644.

Fernando, Priyanthi, \& Porter, Gina (2002). Balancing the load: women, gender and transport. London, UK: Zed Books.

Freilla, Omar (2004). Burying Robert Moses's Legacy in New York City. In Robert Bullard, Glenn Johnson, \& Angel Torres (Eds.), Highway Robbery: Transportation Racism and New routes to Equity (pp. 75-99). Boston, Massachusetts: South End Press.

Gibson, Karen J. (2007). Bleeding Albina: A History of Community Disinvestment, 1940-2000. Transforming Anthropology, 15(1), 3-25.

Golub, Aaron, \& Martens, Karel (2014). Using principles of justice to assess the modal equity of regional transportation plans. Journal of Transport Geography, 41(Supplement C), 10 20.

Goodling, Erin (2019). Urban Political Ecology from Below: Producing a "Peoples' History" of the Portland Harbor. Antipode, $\mathrm{O}(0)$.

Goodling, Erin, Green, Jamaal, \& McClintock, Nathan (2015). Uneven development of the sustainable city: shifting capital in Portland, Oregon. Urban Geography, 36(4), 504-527.

Harvey, David (1989). From Managerialism to Entrepreneurialism: The Transformation in Urban Governance in Late Capitalism. Geografiska Annaler. Series B. Human Geography, 317.

Hoffmann, Melody L. (2015). Recruiting people like you: Socioeconomic sustainability in Minneapolis's bicycle infrastructure. In Stephen Zavestoski \& Julian Agyeman (Eds.), Incomplete Streets: Processes, Practices and Possibilities. London: Routledge Taylor \& Francis Group (pp. 139-153). New York, New York: Routledge, Taylor \& Francis Group.

Hoffmann, Melody L. (2016). Bike Lanes Are White Lanes: Bicycle Advocacy and Urban Planning (1st edition.). Lincoln: University of Nebraska Press.

Karner, Alex, \& Niemeier, Deb (2013). Civil rights guidance and equity analysis methods for regional transportation plans: a critical review of literature and practice. Journal of Transport Geography, 33, 126-134.

Krumholz, Norman (1982). A retrospective view of equity planning Cleveland 1969-1979. Journal of the American Planning Association, 48(2), 163-174.

Krumholz, Norman, \& Forester, John (2011). Making equity planning work: Leadership in the public sector. Philadelphia, PA: Temple University Press.

Kwan, Mei-Po (2002). Feminist visualization: Re-envisioning GIS as a method in feminist geographic research. Annals of the association of American geographers, 92(4), 645661.

Kwan, Mei-Po (2004). GIS Methods in Time-Geographic Research: Geocomputation and Geovisualization of Human Activity Patterns. Geografiska Annaler. Series B, Human Geography, 86(4), 267-280.

Leszczynski, Agnieszka (2009). Poststructuralism and GIS: is there a 'disconnect'? Environment and Planning D: Society and Space, 27(4), 581-602.

Leszczynski, Agnieszka, \& Elwood, Sarah (2015). Feminist geographies of new spatial media. The Canadian Geographer/Le Géographe canadien, 59(1), 12-28.

$\mathrm{Li}$, Wei, \& Joh, Kenneth (2017). Exploring the synergistic economic benefit of enhancing neighbourhood bikeability and public transit accessibility based on real estate sale transactions. Urban Studies, 54(15), 3480-3499.

Liu, Jenny (2016). Portland Green Loop Economic Analysis. Portland, Oregon: Portland State University.

Long, Joshua (2016). Constructing the narrative of the sustainability fix: Sustainability, social justice and representation in Austin, TX. Urban Studies, 53(1), 149-172.

Lowery, Damon R., \& Morse, Wayde C. (2013). A qualitative method for collecting spatial data on important places for recreation, livelihoods, and ecological meanings: integrating focus groups with public participation geographic information systems. Society \& Natural Resources, 26(12), 1422-1437. 
Mahmoudi, Lubitow, and Christensen. "Reproducing spatial inequality? The sustainability fix and barriers to urban mobility in Portland, Oregon." Accepted for publication in Urban Geography. For up-to-date journal version with page numbers, please see: https://doi.org/10.1080/02723638.2019.1698865

Lubitow, Amy, \& Miller, Thaddeus R. (2013). Contesting Sustainability: Bikes, Race, and Politics in Portlandia. Environmental Justice, 6(4), 121-126.

Martens, Karel (2016). Transport Justice: Designing fair transportation systems (1 edition.). New York, New York: Routledge.

Martens, Karel, Golub, Aaron, \& Robinson, Glenn (2012). A justice-theoretic approach to the distribution of transportation benefits: Implications for transportation planning practice in the United States. Transportation Research Part A: Policy and Practice, 46(4), 684-695.

Massey, Douglas S., \& Denton, Nancy A. (1993). American Apartheid: Segregation and the Making of the Underclass. Cambridge, Massachusetts: Harvard University Press.

McCarthy, James, \& Prudham, Scott (2004). Neoliberal nature and the nature of neoliberalism. Geoforum, 35(3), 275-283.

McKenzie, Brian S. (2013). Neighborhood access to transit by race, ethnicity, and poverty in Portland, OR. City \& Community, 12(2), 134-155.

McLafferty, Sara, \& Tempalski, Barbara (1995). Restructuring and women's reproductive health: Implications for low birthweight in New York City. Geoforum, 26(3), 309-323.

Pellow, David Naguib (2017). What is Critical Environmental Justice? Cambridge, UK: Polity.

Pereira, Rafael H. M., Schwanen, Tim, \& Banister, David (2017). Distributive justice and equity in transportation. Transport Reviews, 37(2), 170-191.

Prudham, Scott (2009). Pimping climate change: Richard Branson, global warming, and the performance of green capitalism. Environment and planning A, 41(7), 1594-1613.

Rast, Joel (2006). Environmental justice and the new regionalism. Journal of planning education and research, 25(3), 249-263.

Rosol, Marit (2014). On resistance in the post-political city: conduct and counter-conduct in Vancouver. Space and Polity, 18(1), 70-84.

Roy, Ananya (2005). Urban Informality: Toward an Epistemology of Planning. Journal of the American Planning Association, 71(2), 147-158.

Sanchez, Thomas (2008). The Right to Transportation: Moving to Equity (1 edition.). Chicago, IL: Routledge.

Schuurman, N. (2009). Critical GIS. In Rob Kitchin \& Nigel Thrift (Eds.), International Encyclopedia of Human Geography (pp. 363-368). Oxford: Elsevier.

Sheller, Mimi (2012). Sustainable mobility and mobility justice: towards. In Margaret Grieco \& John Urry (Eds.), Mobilities: New Perspectives on Transport and Society (pp. 289-304). New York, New York: Routledge.

Squires, Gregory D., Velez, William, \& Taeuber, Karl E. (1991). Insurance redlining, agency location, and the process of urban disinvestment. Urban Affairs Quarterly, 26(4), 567588.

Sultana, Selima, Salon, Deborah, \& Kuby, Michael (2017). Transportation sustainability in the urban context: a comprehensive review. Urban Geography, 40(3), 279-308.

Swyngedouw, Erik (2014). Insurgent architects, radical cities, and the promise of the political. In Japhy Wilson \& Erik Swyngedouw (Eds.), The Post-Political and its Discontents (pp. 169188). Edinburgh, UK: Edinburgh University Press.

Talen, Emily (2011). Geovisualization of Spatial Equity. In Timothy Nyerges, Helen Couclelis, \& Robert McMaster (Eds.), The SAGE Handbook of GIS and Society (pp. 458-479). London, UK: SAGE Publications Ltd.

Talen, Emily, \& Anselin, Luc (1998). Assessing spatial equity: an evaluation of measures of accessibility to public playgrounds. Environment and planning A, 30(4), 595-613.

Thatcher, Jim, Bergmann, Luke, Ricker, Britta, Rose-Redwood, Reuben, O'Sullivan, David, Barnes, Trevor J., ... Young, Jason C. (2016). Revisiting critical GIS. Environment and Planning A, 48(5), 815-824.

Thomas, David R. (2006). A general inductive approach for analyzing qualitative evaluation data. American journal of evaluation, 27(2), 237-246.

Walker, Gordon (2009). Beyond Distribution and Proximity: Exploring the Multiple Spatialities of Environmental Justice. Antipode, 41(4), 614-636. 
Mahmoudi, Lubitow, and Christensen. "Reproducing spatial inequality? The sustainability fix and barriers to urban mobility in Portland, Oregon." Accepted for publication in Urban Geography. For up-to-date journal version with page numbers, please see: https://doi.org/10.1080/02723638.2019.1698865

Ward, Kevin (2003). Entrepreneurial urbanism, state restructuring and civilizing 'New' East Manchester. Area, 35(2), 116-127.

While, Aidan, Jonas, Andrew E. G., \& Gibbs, David (2004). The environment and the entrepreneurial city: searching for the urban 'sustainability fix' in Manchester and Leeds. International Journal of Urban and Regional Research, 28(3), 549-569.

Winner, Langdon (1989). Do Artifacts Have Politics? In The Whale and the Reactor: A Search for Limits in an Age of High Technology. London: University of Chicago Press. 